\title{
Inovasi Birokrasi Pelayanan Publik Program Raskin Pola Padat Karya Pangan (RASKIN POLA PKP) di Kabupaten Timor Tengah Utara
}

\author{
Tri Anggraini ${ }^{1}$ \\ Marisa S.B Seran ${ }^{2}$ \\ Ilmu Administrasi Negara, Fakultas Ilmu Sosial dan Ilmu Politik ${ }^{1}$ \\ Ilmu Pemerintahan, Fakultas Ilmu Sosial dan Ilmu Politik ${ }^{2}$ \\ Universitas Timor \\ Jalan Km. 09 Kelurahan Sasi, Kota Kefamenanu, \\ Nusa Tenggara Timur
}

Received: 8th August 2020; Revised: 12th September 2020; Accepted: 13th September 2020

\begin{abstract}
In Indonesia the drive to create public service innovations has become a new trend in efforts to improve services to the public. One of them is Public Service Innovation named Raskin PKP Pattern. This research will look at the PKP Raskin Innovation pattern, Supporting Factors and inhibiting factors as well as about the obstacles in implementing the PKP Pattern Raskin Innovation in TTU District. The method used is descriptive qualitative observation and in-depth interviews. The results showed that the PKP innovation Raskin was born from the internal government of TTU Regency as an effort to develop the agricultural sector. This innovation has many advantages for the community, taking into account the conditions and previous agricultural patterns and maintaining local values that exist in the community. This innovation is not intended to be an innovation of low complexity because it is very possible to be tested and easy to observe. the supporting factor that drives the successful implementation of the PKP Raskin program is the Leader's Commitment. Whereas the inhibitor of the PKP Pattern Raskin Innovation was the lack of support from the legislature.
\end{abstract}

Keywords: innovation; bureaucracy; public services

\begin{abstract}
ABSTRAK
Di Indonesia Dorongan untuk menciptakan inovasi pelayanan publik telah menjadi tren baru dalam upaya peningkatan pelayanan kepada masyarakat. Salah satunya Inovasi Pelayanan publik yang diberi nama Raskin Pola PKP. Artikel ini akan melihat inovasi Raskin Pola PKP. Fakor Pendukung dan faktor penghambat sekaligus tentang kendala yang dalam penerapan Inovasi Raskin Pola PKP di Kabupaten TTU. Metode yang digunakan adalah deskriptif kualitatif dengan metode observasi dan wawancara mendalam. Hasil penelitian menunjukkan bahwa Inovasi Raskin pola PKP ini lahir dari internal pemerintah Kabupaten TTU sebagai upaya pengembangan pada sector pertanian. Inovasi ini memiliki banyak keuntungan bagi masyarakat, dengan mempertimbangkan kondisi dan pola pertanian sebelumnya dan mempertahankan nilainilai local yang ada dimasyarakat. Inovasi ini tidak termaksud dalam inovasi dalam
\end{abstract}


tingkat kerumitan rendah karena sangat memungkinkan untuk diuji coba dan kemudahan untuk diamati. faktor pendukung yang mendorong keberhasilan penyelenggaraan program Raskin pola PKP ini adalah Komitmen Pemimpin. Sedangkan fator penghambat Inovasi Raskin Pola PKP ini adalah minimnya dukungan dari pihak legislative

Kata kunci: inovasi; birokrasi; pelayanan public

\section{PENDAHULUAN}

Dalam kancah global, Posisi Indonesia belum menggembirakan. Pada berbagai indeks internasional, Indonesia masih menempati urutan rendah, bahkan di tingkat negara-negara Asia Tenggara sekalipun. Salah satunya adalah tentang posisi dan keadaan Inovasi di Indonesia, Dalam Global Innovation Index (GII) Tahun 2015, Indonesia menempati peringkat 97dengan skor 29,79 turun dari peringkat 87 dengan skor 31,8 pada tahun 2014. Posisi Indonesia ini berada dibawah negara-negara di kawasan ASEAN seperti Vietnam yang menempati peringkat 52, Thailand dengan peringkat 55, Malaysia dengan peringkat 32 dan Singapura berada pada 10 besar yaitu peringkat ke 7 .

Inovasi menjadi tool dalam mengakselerasikan peningkatan daya saing Indonesia. Setiap element negara yang meliputi pemerintah, swasta dan masyarakat sipil harus melakukan inovasi. Inovasi pada lingkungan instansi pemerintah meliputi antara lain kementerian, lembaga pemerintah non kementerian, Pemerintah Provisi dan Pemerintah Kabupaten/Kota sangat penting karena dapat mengakselerasikan inovasi swasta dan masyarakat dalam meningkatkan pelayanan publik.

Pada dasarnya Inovasi merupakan bagian yang tak terpisahkan dari reformasi birokrasi. Reformasi birokrasi dirancang untuk memperbaiki penyakitpenyakit disektor publik melalui pembaharuan di 8 area sasaran (organisasi, tata laksana, peraturan perundangan-undangan, SDM aparatur, pengawasan, akuntabilitas, pelayanan publik dan mindset serta cultural set aparatur). Inovasi menjadi katalisator untuk mempercepat pelaksanaan reformasi birokrasi, dimana banyak program inovasi merupakan pengejawataan dari upaya perubahan diarea-area tersebut. Lebih jauh lagi, inovasi sesungguhnya dapat dimaknai sebagai reformasi birokrasi kontekstual, artinya pelaksanaan reformasi birokrasi yang disesuaikan dengan kebutuhan dan tantangan daerah setempat.

Kesadaran pentingnya inovasi saat ini ditandai degan telah diterbitkannya Undang-Undang No 23 tahun 2014 tentang Pemerintah Daerah yang memberikan peluang pemerintah daerah untuk melakukan inovasi. Selain melalui Undang-Undang No 23 tahun 2014 bukti konkrit dari dukungan pemerintah ini diwujudkan melalui Kompetensi Inovasi Pelayanan Publik yang merupakan wujud dari Program One Agency One Innovation yang mewajibkan Kementerian atau Lembaga dan Pemerintah Daerah untuk mencipatakan minimal satu inovasi setiap tahunnya. Apesiasi nyata diberikan Pemerintah kepada Kementerian atau Lembaga serta Pemerintah daerah melalui Keputusan Menteri Pendayagunaan Aparatur Sipil Negara dan Reformasi Birokrasi (PANRB) No. 636/2018, menetapkan 40 terbaik untuk inovasi pelayanan publik dimana Kementerian dan Lembaga yang memenangkan Kompetensi Inovasi Pelayanan Publik ini akan mendapatkan Alokasi Dana Intensif Daerah (DID). 
Top 40 Inovasi Pelayanan Publik Tahun 2018 merupakan inovasi yang dikategorikan outstanding (terpuji) hasil seleksi dari Top 99. Proses kompetisi ini dilakukan secara online melalui aplikasi berbasis web Sistem Informasi Inovasi Pelayanan Publik (SINOVIK) melalui http://sinovik.menpan.go.id. telah terekam sebanyak 2.824 inovasi pelayanan publik di Kompetisi Inovasi Pelayanan Publik Penilaian kompetisi dilakukan secara independen oleh Tim Evaluasi dan Tim Panel Independen yang merupakan para akademisi, praktisi, dan pakar pelayanan publik yang kompeten dan memiliki reputasi baik. Top 40 Inovasi Pelayanan Publik Tahun 2018 terdiri dari lima inovasi kementerian, dua inovasi Kepolisian Negara RI, delapan inovasi pemerintah provinsi, 15 inovasi kabupaten, dan 10 inovasi dari pemerintah kota. Adapun penganugerahan Penghargaan kepada Top 40 Inovasi Pelayanan Publik Tahun 2018 dilaksanakan Hotel Shangri La, Surabaya pada 19 September 2018.

Salah satu penerima penghargaan TOP 99 Inovasi terbaik di Indonesia adalah Kabupaten Timor Tengah Utara melalui Program Inovasi Raskin Pola Padat Karya Pangan atau disingkat RASKIN POLA PKP. Pogram yang mendapatkan apresiasi tinggi ini dalam perjalanan lahirnya terjadi polemik berupa penolakan dari DPRD Kabupaten TTU, tidak hanya mendapatkan penolakan, tetapi juga dilanjutkan dengan memprovokasi masyarakat untuk tidak ikut serta dalam program ini. (GenBest.id, 2018) Karena pada dasarnya, pemanfaatan lahan kering untuk per- tanian sering diabaikan oleh para pengambil kebijakan, yang lebih tertarik pada peningkatan produksi beras pada lahan sawah. (A. Abdurachman, A. Dariah, 2008).

Hambatan lain yang terjadi selama tahun awal implementasi inovasi pelayanan publik ini adalah, Anggaran dalam program juga dipangkas sedemikian rupanya oleh DPRD, sebagai bentuk penolakan implementasi program Inovasi Pelayanan Publik ini. Dalam salah satu berita online Bupati Kabupaten TTU Raymundus mengungkapkan bahwa Program Inovasi Raskin pola PKP ini tidak mendapatkan dukungan dari DPRD Namun komitmen Pemerintah Kabupaten TTU untuk tetap meneruskan Program inovasi ini. (GenBest.id, 2018). Terdapat hubungan antara penerapan atau adopsi inovasi teknologi pertanian dengan tingkat ketahanan rumah tangga petani. Terbukti di Desa Cibeber Ipetani yang lebih intensif menerapkan inovasi teknologi seperti jajar legowo memiliki tingkat ketahanan pangan yang lebih baik. ((Fatchiya et al., 2016).

Polemik dan penolakan yang terjadi dari lahirnya program ini nyatanya dijadikan angin lalu oleh Pemerintah TTU, Program RASKIN POLA PKP tetap dilanjutkan dan mengimpelemtasikan Program Raskin Pola PKP pada 2011. Nyatanya, Program ini mendulang keberhasilan dengan berhasil menurunkan tingkat kemiskinan di Kabupaten TTU hingga 22 yang sebelumnya Kabupaten TTU merupakan kabupaten dengan angka kemiskinan tertinggi, Dimana 62\% kemiskinan Nusa Tenggara Timur ada di Kabupaten TTU. Berangkat dari hal tersebut, Pemerintah Kabupaten TTU meramu sejumlah program unggulan khususnya untuk mendongkrak pemenuhan kebutuhan sandang, pangan dan papan selain sebagai upaya peningkatan kesejahteraan masyarakat juga sebagai upaya untuk keluar dari daerah tertinggal.

Pelaksanaan Raskin Pola PKP dimaksudkan untuk memanfaatkan lahan tidur (lahan basah dan lahan kering potensial), mengurangi sistem tebas bakar dan perladangan berpindah, memperkecil erosi permukaan dan menjaga 
kelestarian lingkungan melalui sistem wanatani lahan dan pembuatan terasering. Pada dasarnya program ini adalah upaya pemerintah Kabupaten TTU untuk mengatasi masalah pangan karena salah satu kriteria kemiskinan bagi petani adalah luas lahan garapan tidak boleh kurang dari 50 are dan minimal setengah hektar.

Salah satu bentuk dorongan yang dilakukan Pemerintah TTU sebagai upaya untuk peningkatan perluasan lahan pertanian adalah dengan Program Padat Karya Pangan yakni dengan mengkonversikan beras raskin yang diberikan kepada KK miskin secara gratis oleh pemerintah daerah dengan kompensasi KK miskin tersebut harus menambah luas garapan pertanian seluas $25 \mathrm{Ha}$ pertahunnya dengan harapan bahwa petani memiliki luas lahan yang cukup dalam pertanian dan tidak berpindah-pindah.

Program yang telah menurunkan angka kemiskinan yang sebelumnya pada angka $62,62 \%$ ke angka $21,22 \%$ ini tidak hanya masuk dalam top 40 Inovasi terbaik di Indonesia. Program RASKIN POLA PKP juga berhasil menyambet 15 Inovasi terbaik untuk pemerintah Kabupaten di Indonesia. Oleh karena itu, Penting kiranya menilik lebih detail bagaimana Inovasi Birokrasi Pelayanan Publik ini sehingga mampu mendorong inovasi-inovasi bersifat lokal dan instansional, tetapi potensial untuk diterapkan secara nasional diangkat menjadi program nasional sesuai dengan harapan Kementerian PANRB.

Oleh karena itu, Penelitian ini akan mengkaji tentang Inovasi Birokrasi Pelayanan Publik Dinas Pertanian Kabupaten TTU melalui Program Raskin Pola Padat Karya Pangan (RASKIN POLA PKP). Pelayanan sendiri dalam kamus Besar Bahasa Indonesia didefinisikan sebagai perihal atau cara meladeni dan kemudahan yang diberikan sehubungan dengan jual beli barang atau jasa. Sedangkan Inovasi Pelayanan publik diartikan oleh Lembaga Administrasi Negara sebagai segala bentuk kegiatan pelayanan umum yang dilaksanakan oleh Instansi Pemerintahan di Pusat dan Daerah, dan di lingkungan BUMN/BUMD dalam bentuk barang dan /atau jasa, baik dalam pemenuhan kebutuhan masyarakat. Menurut Damanpour (Suwarno, 2008). Inovasi bisa berupa produk maupun jasa yang sistem struktur administrasi atau rencana baru bagi anggota organisasi. Jadi, Inovasi Pelayanan Publik dimaknai sebagai pergeseran makna, prinsip-prinsip, proses, prosedur dan model pelayanan publik yang lama ke yang baru dan dirancang untuk memberikan keuntungan bagi individu, kelompok, dan organisasi dan masyarakat pada umumnya (Basuki, 2013).

Lebih lanjut, Penelitian ini akan menggunakan teori atribut inovasi pelayanan Menurut Rogers (Suwarno, 2008) yang dijadikan aspek, yaitu Relatve Advantage (Keuntungan Relative), Compability (Kesesuaian), Complexity (kerumitan), triability (kemungkinan untuk dicoba) dan observability (kemudahan diamati). Penulis memandang 5 variabel ini telah memadai untuk menjelaskan Inovasi Birokrasi Pelayanan Publik Dinas Pertanian Kabupaten TTU melalui Program Raskin Pola Padat Karya Pangan (RASKIN POLA PKP), Lebih detail penelitian ini juga akan melihat kendala-kendala yang dihadapi serta Faktor Pendukung dan factor penghambat dalam Pelaksanaan Inovasi Birokrasi Pelayanan Publik Dinas Pertanian Kabupaten TTU melalui Program Raskin Pola Padat Karya Pangan (RASKIN POLA PKP). 


\section{METODE PENELITIAN}

Penelitian ini dilakukan menggunakan penelitian kualitatif dengan alasan bahwa metode ini ini diekspektasikan mampu mendeskripsikan analisis berupa teks atau narasi secara mendalam (Creswell, 2014). Dengan melihat fenomena yang akan dikaji metode studi kasus dipilih diawali dengan teori-teori yang spesifik. Sedangkan metode yang digunakan dalam penelitian ini adalah deskriptif analitis. Pemilihan pendekatan kualitatif ini juga dinilai penulis lebih tepat digunakan untuk memahami dan menggambarkan kondisi lapangan, fenomena-fenomena inovasi Raskin Pola PKP, serta lebih tepat digunakan untuk melihat aktor pendukung dan penghambat dan kendala-kendala yang dihadapi dalam mengimplementasikan Inovasi Raskin Pola PKP secara lebih terperinci.

Teknik pengumpulan data dalam penelitian ini dilakukan menggunakan teknik pengumpulan data berupa studi kepustakaan dan studi lapangan. Studi lapangan dilakukan diantaranya dengan observasi dan wawancara semi struktur. Pemilihan Narasumber dilakukan secara purposive yaitu orang-orang yang memiliki kecukupan pengetahuan dan mampu menjelaskan keadaan yang sebenarnya sesuai dengan kebutuhan penelitian. Kepala Dinas Pertanian, Sekretaris Dinas Pertanian dan stakeholder lain pendukung dalam Inovasi Raskin Pola PKP. Selanjutnya hasil wawancara ditranskipkan menjadi analisis kualitatif menggunakan 3 alur secara bersamaan, yaitu reduksi data, penyajian data, dan penarikan kesimpulan. Reduksi data dilakukan secara terus menerus selama kegiatan untuk melihat secara langsung fenomena yang terjadi dalam inovasi Raskin Pola PKP. Sedangkan penyajian sebagai sekumpulan informasi tersusun yang memberi kemungkinan adanya penarikan kesimpulan dan pengambilan tindakan. Pada penarikan kesimpulan dilakukan pula verifikasi dengan proses berpikir kembali dan meninjau ulang catatan-catatan lapangan (Miles B, Mathew, 1992).

\section{HASIL DAN PEMBAHASAN}

Program Raskin Pola PKP merupakan program unggulan Pemerintah Kab. TTU tertuang dalam Panca Program Strategis Kab. TTU sebagai upaya pengembangan sektor pertanian di Kab.TTU dengan mengolaborasikan pelaksanaan program Raskin. Berbeda dengan pola pembagian raskin nasional, yang umumnya menebus raskin dengan harga murah yakni Rp. $1.600 .00 / \mathrm{kg}$, namun memalui program raskin pola PKP ini masyarakat diharuskan menebus raskin dengan pola ganti kerja yaitu pengelolaan lahan pertanian. Inovasi ini mengharuskan masyarakat yang menjadi rumah tangga sasaran penerima program raskin nasional untuk mengelola lahan sendiri dengan Pola Padat Karya Pangan.

Setiap organisasi memiliki kebutuhan inovasi yang berbeda. Ada organisasi yang melakukan inovasi tertutup dan inovasi terbuka (Victorino et al., 2005) Inovasi Raskin Pola PKP ini apabila dilihat dari jenis inovasi dapat digolongkan menjadi inovasi tertutup, menurut Helfat Inovasi tertutup merupakan kegiatan inovasi internal organisasi yang dilakukan dalam bentuk penelitian dan pengembangan organisasi serta telah sukses dilakukan oleh organisasi. Sedangkan inovasi terbuka yaitu organisasi yang muncul dari sumber eksternal organisasi, namun tetap dilakukan kemitraan bersama internal organisasi (Tsou, H. T., \& Hsu, 2011). Inovasi Raskin Pola PKP ini dapat digolongkan sebagai jenis Inovasi tertutup. Dikatakan inovasi tertutup dikarenakan lahirnya inovasi ini 
berasal dari internal organisasi Pemerintah Daerah Kab.TTU yaitu Dinas Pertanian Kab.TTU sebagai leading sektor dan Bupati Timor Tengah Utara, Bapak Raymundus Sau Fernandes,S.Pt dan Bapak Wakil Bupati Timor Tengah Utara, Bapak Aloysius Kobes, S.Sos sebagai inisiator Program Raskin Pola PKP sebagai upaya pengembangan di sektor publik. Inovasi juga dapat diartikan sebagai salah satu bentuk perubahan di sektor publik (Colville, I., \& Carter, 2012).

Suatu inovasi dipandang absah jika mampu memberikan perubahan yang positif melalui satuan yang terukur (Jordan \& Huitema, 2014). Pengembangan sektor pertanian di Kab.TTU ini dilatar belakangi oleh Kab. TTU merupakan salah satu Kabupaten di Provinsi Nusa Tenggara Timur dengan luas wilayah 2.669,70 Km2 dan memiliki lahan pertanian seluas 210.456 Ha. Pada tahun 2010 sebelum inovasi Raskin Pola PKP, dengan jumlah masyarakat petani sebanyak 60.497 jiwa dan jumlah keluarga miskin sebanyak 34.832 KK 65,62\%. Salah satu ukuran kemiskinan yakni ketidakmampuan masyarakat memenuhi kebutuhan dasar sandang, pangan dan papan. Kondisi kemiskinan ini berdampak pada segala aspek kehidupan masyarakat di Kab. TTU. Melalui program Raskin Pola PKP ini telah menurunnya jumlah penduduk dan rumah tangga miskin, Data jumlah penduduk dan rumah tangga miskin pada tahun 2011 yaitu hingga mencapai 65,62\% namun pada tahun 2016 telah terjadi penurunan secara signifikan hingga mencapai $24,07 \%$ dengan rata-rata penurunan angka kemiskinan per tahun adalah $8,31 \%$ atau setara $2.895 \mathrm{KKM}$ per tahun.

Kab. TTU memiliki lahan kering potensial seluas 187.650 Ha dan lahan basah potensial seluas $3.123 \mathrm{Ha}$. Potensi lahan pertanian ini tidak dimanfaatkan secara maksimal karena dibiarkan dalam kondisi yang terbengkalai atau tidak dimanfaatkan untuk lahan pertanian yang produktif. rendahnya produktivitas lahan pertanian, serta pengerjaan kebun dilakukan dengan pola tebas bakar dan perladangan berpindah tanpa teknik budidaya yang baik sehingga menyebabkan kerusakan lahan pertanian, tingginya erosi permukaan dan tingginya kerusakan hutan. Kondisi inilah yang mendorong pemerintah Kab.TTU meluncurkan Inovasi dalam program Raskin Pola PKP. Inovasi Raskin Pola PKP mampu meningkatkan pemanfaatan lahan kering dan lahan basah sesuai dengan teknis pertanian yang mengutamakan kelestarian lahan, setidaknya terjadinya peningkatan pemanfaatan Lahan kering 8.282 Ha pada tahun 2011 menjadi 86.582 Ha pada tahun 2017 dan lahan basah 11.401 Ha di tahun 2011 menjadi 14.267 Ha di tahun 2017.

Program Raskin Pola PKP merupakan terobosan yang dilakukan oleh Pemerintah Kab. TTU untuk mengatasi masalah kemiskinan dan ketidakcukupan pangan dengan mengkonversi raskin nasional mengharuskan Masyarakat yang menjadi Rumah Tangga Sasaran penerima program raskin nasional untuk mengelola lahan sendiri dengan Pola Padat Karya Pangan. Program ini berbeda dari program raskin nasional, secara nasional Rumah Tangga Sasaran (RTS) membayar harga tebus raskin sebesar Rp. 1.600,/kg sedangkan melalui Raskin Pola PKP masyarakat menerima raskin secara gratis dengan kewajiban mengerjakan kebunnya sendiri seluas 0,25 Ha per tahun. Pelaksanaan raskin Pola PKP dimaksudkan untuk memanfaatkan lahan tidur (lahan basah dan lahan kering potensial), mengurangi sistem tebas bakar dan perladangan berpindah, memperkecil erosi permukaan dan menjaga kelestarian 
lingkungan melalui olah jalur dan olah lubang (konservasi lahan) dan pembuatan terasering yang tersebar pada 194 Desa/Kelurahan yang tersebar di 24 Kecamatan.

Menurut Mulgan dan Albury (Muluk, 2008) berkenan dengan Level Inovasi yang mencerminkan variasi besarnya dampak yang ditimbulkan oleh inovasi yang berlangsung. Menjawab mengenai level inovasi, Program Raskin Pola PKP ini berada pada level inkremental. Inovasi Inkremental merupakan inovasi yang terjadi membawa perubahan-perubahan kecil. Terhadap proses atau layanan yang ada. Umumnya Sebagian besar inovasi berada dalam level ini dan jarang sekali membawa perubahan terhadap struktur organisasi dan hubungan keorganisasian. Inovasi raskin pola PKP ini digolongkan sebagai level inkemental dikarenakan hanya mengubah pola pertanian tradisional menjadi pola pertanian dengan Padat Karya Pangan dengan perpaduan komponen tanaman hutan dan pertanian. Perubahan pola pertanian ini memiliki keunggulan yaitu mendorong masyarakat untuk berkebun menetap dengan mengkombinasikan tanaman semusim (pangan dan hortikultura) dan tanaman tahunan/kayu/kehutanan dengan lima kegiatan utama.

Sebuah inovasi harus mempunyai keunggulan dan nilai lebih dibandingkan dengan inovasi sebelumnya. Selalu ada sebuah nilai kebaruan yang melekat dalam inovasi yang menjadi ciri yang membedakannya dengan yang lainnya (Suwarno, 2008). Selain mendorong masyarakat untuk pertanian secara menetap Pola Padat Karya Pangan juga mendorong masyarakat menerapkan pertanian berkelanjutan. Penerapan konsep pertanian yang menetap dan berkelanjutan ini memberikan keuntungan relatif pada masyarakat. Keuntungan relatif (Relative advantange) artinya inovasi yang diciptakan oleh organisasi harus memiliki keuntungan dan nilai lebih dibandingkan dengan inovasi sebelumnya. (Miles B, Mathew, 1992). Jika melihat keuntungan relative, Perubahan berdampak dengan adanya perubahan perilaku masyarakat yang sebelumnya melakukan pengolahan kebun berpindah dengan pola tebas bakar, menjadi masyarakat yang peduli terhadap pengelolaan kebun secara menetap dan berkelanjutan. Sistem pertanian dengan cara menetap ini berdampak pada lahan pertanian mampu berproduksi secara stabil sepanjang tahun sehingga berdampak pada kestabilan ekonomi petani karena tidak terjadinya pasang surut komoditas yang terlalu signifikan.

Inovasi hanya bisa diterima apabila telah teruji dan terbukti mempunyai keuntungan atau nilai lebih dibandingkan dengan inovasi yang lama (Suwarno, 2008). Selain itu keuntungan lain perubahan pola pertanian dengan Padat Karya Pangan ini juga dapat mencegah kerusakan lingkungan dan memperhatikan penggunaan pupuk secara alami karena para petani meninggalkan pola tebas bakar yang selama ini digunakan. Tidak hanya itu, Pola PKP ini juga memberikan keuntungan lain, yaitu adanya peningkatan pendapatan petani, dalam data Dinas Pertanian Kab.TTU pendapatan petani pada tahun 2010 sebesar Rp. 4.081.912,00 menjadi Rp. 5.567.626,00 di tahun 2016. Hal ini selaras dengan hasil wawancara penulis dengan salah satu petani sebagai pengguna manfaat Inovasi Raskin pola PKP, sebagai berikut:

Program PKP yang sebelumnya belum ada di desa kami, kami belum tahu untuk pengelolaan tanah, utamanya teras sering, pengelolaan lubang sampai tingkat pemupukan, setelah adanya program Pola PKP ini kami ibu-ibu kami jadi tahu, dan itu bermanfaat karena sayur mayur sangat subur sehingga kami 
dapat jual untuk dapatkan uang dan dapat menambah penghasilan dalam keluarga, dapat mendukung penghasilan para bapak di dalam keluarga kami, ditambah lagi, kami dapat beras raskin tidak usa membayar lagi, cukup dengan bertani. harapan kami program ini dapat berlanjut.

Dari pernyataan tersebut diatas, dapat diketahui bahwa masyarakat tidak hanya mendapatkan manfaat dari pola pertanian PKP tetapi juga mendapatkan manfaat bahwa tidak harus menebus raskin yang diberikan dengan uang karena pemerintah Kab.TTU yang telah menggangarkan subsidi beras Raskin bagi masyarakat penerima manfaat dari Raskin Pola PKP sebesar Rp. 36.751.392.000.

Inovasi selalu berhubungan erat dengan ide-ide baru yang bermanfaat (Anggraini, 2019). Selain itu, keuntungan lain didapat adalah adanya peningkatan hasil pertanian dan perluasan lahan pertanian para petani. Menurut data Dinas Pertanian Kabupaten TTU adanya peningkatan Luas olahan lahan kering sampai dengan tahun 2017 mencapai $27.092 \mathrm{Ha}$, atau meningkat $8 \%$ (2.006 Ha) dibanding tahun 2015/2016, Lahan yang ditanami Tanaman Umur Panjang (TUP) sebanyak 20.558 Ha (4.762.237 pohon) dari 14 jenis tanaman, Pengerjaan sawah sampai dengan tahun 2017 meningkat 4\% (333 Ha) dibandingkan tahun 2016. Pengembangan berbagai tanaman sisipan bernilai ekonomis (kunyit, nenas, perorang, dll) dan budidaya sayur seluas $350 \mathrm{Ha}$ dengan memanfaatkan sisa air irigasi serta adanya peningkatan Produktifitas pertanian pada musim tanam tahun 2016 khusus tanaman jagung meningkat menjadi 4,08 ton/Ha, dan tanaman padi meningkat menjadi 3,79 ton/Ha.

Tidak hanya memperhatikan keuntungan yang didapatkan, Inovasi diciptakan dengan tetap mempertahankan kegunaan serta integrasi dengan aplikasi yang sudah ada (Miles B, Mathew, 1992). Lahirnya inovasi raskin pola PKP ini adalah bagian upaya pemerintah untuk memaksimalkan sektor pertanian dengan jumlah masyarakat petani mencapai 60.497 jiwa. Inovasi raskin pola PKP ini merupakan upaya pengembangan sektor pertanian dengan mempertimbangkan kondisi dan pola pertanian sebelumnya. Seperti yang dijelaskan oleh Perwakilan Dinas Pertanian Kabupaten TTU, bahwa inovasi ini menyesuaikan dengan kondisi dan pola pertanian sebelumnya, ada jenis-jenis pola pertaniannya menyesuaikan kondisi tanah dan lahan. Misal kalo lahan kering, kita menggunakan sistem wanatani.

Sesuai dengan hasil wawancara diatas, Inovasi Raskin Pola Padat Karya Pangan ini memiliki 3 tipe pekerjaan yaitu tipe pekerjaan pada areal lahan kering, tipe pekerjaan pada areal lahan basah dan tipe pekerjaan areal pekarangan khusus pada daerah dengan lahan pertanian yang sempit terutama di Kecamatan Kota Kefamenanu. Pada masing-masing tipe pekerjaan mempunyai pola atau jenis perkerjaan yang spesifik sesuai dengan arealnya sehingga diharapkan hasil pertanian dapat stabil dari waktu ke waktu. Penyesuaian Pola pertanian dengan pola pertanian sebelumnya dimaksudkan agar inovasi yang lama tidak serta merta dibuang begitu saja, selain karena alasan faktor biaya yang sedikit namun juga inovasi yang lama dapat menjadi bagian dari proses transisi ke inovasi baru. (Miles B, Mathew, 1992).

Dalam wawancara yang dilakukan penulis dengan perwakilan Dinas Pertanian diketahui bahwa pada masa awal penerapan Inovasi ini, Pemerintah tidak serta merta melakukan perubahan secara signifikan, Keseuaian Inovasi dengan pola sebelumnya juga dapat memudahkan proses adaptasi dan proses 
pembelajaran terhadap inovasi itu secara lebih cepat (Suwarno, 2008). Masyarakat diberikan kesempatan untuk tetap melakukan pola pertanian lama namun tetap menyesuaikan pola pertanian PKP ini, harapannya pola awal penerapan inovasi in dapat menjadi bagian dari transisi masyarakat pada pola pertanian PKP. Seperti pernyataan yang disampaikan oleh salah satu perwakilan Dinas Pertanian bahwa pola pertanian ini hanya penambahan saja pola pertanian lama sebenarnya, misalnya dulu hanya tanam sayur panen lalu selesai, sekarang tidak lagi, bisa ada tanaman selipan dan seterusnya. Diawal kita tidak langsung menerapkan, takut petani kaget. Jadi dibolehkan petani menanam pakai cara yang biasanya, tapi tetap harus menerapkan pola pertanian PKP. Harapannya. Mereka bisa lihat hasil produktifitas pola biasa yang mereka pakai dengan pola PKP ini. Pasti akan berbeda jauh hasilnya. Semacam uji coba begitu.

Dari hasil wawancara diatas, dapat diketahui bahwa Sebuah Inovasi hendaknya dapat disesuaikan dengan nilai, pengalaman masa lalu, dan kebutuhan penerima (Miles B, Mathew, 1992). Inovasi Raskin Pola PKP ini juga memperhatikan nilai-nilai lokal yang melekat dalam masyarakat, salah satunya adalah nilai-nilai gotong royong. Nilai gotong royong yang sangat melekat ini digunakan pemerintah sebagai upaya untuk menumbuhkan rasa kebersamaan sekaligus untuk menekan pengeluaran biaya usaha tani. Oleh karena itu semua penerima manfaat Inovasi Raskin Pola PKP diwajibkan untuk berkelompok.

Dari segi kerumitan, Program Inovasi Raskin Pola PKP ini tergolong mudah diterapkan karena Rumah Tangga Sasaran penerima program raskin nasional hanya diminta untuk berkebun pada ladang sendiri. Kemudahan selanjutnya adalah bagi Rumah Tangga Sasaran penerima program raskin yang ditinggal di Kota dengan lahan pertanian yang terbatas diberikan kemudahan untuk mengelola lahan pertanian dengan memanfaatkan pekarangan rumah yang terbatas dengan kegiatan pengembangan hortikultura atau pengembangan tanaman sayuran di polibag. Inovasi Raskin Pola PKP ini tidak hanya memberikan kemudahan bagi Rumah Tangga Sasaran di kawasan perkotaan tetapi juga Rumah Tangga Sasaran di perdesaan yang tidak memiliki cukup lahan untuk penambahan lahan pertanian, kemudahan berupa diperbolehkan mengelola lahan pertanian milik orang lain. Seperti wawancara yang dilakukan dengan perwakilan Dinas Pertanian Kab.TTU yang mengungkapkan bahwa Bagi masyarakat yang di Kota Kefamenanu, dengan kondisi lahan sempit. Tetap bisa mengikuti program ini. Cukup dengan memaksimalkan lahan pekarangan rumah. Dengan menanam sayur, cabe contohnya di polibek. Nanti ada tim yang datang memantau, mengecek apakah ada tanaman yang ditanam atau tidak, nanti baru dapat diputuskan. Sedangkan bagi petani di desa yang tidak memiliki lahan pertanian untuk menambah, boleh menggunakan lahan orang lain.

Dengan melihat kemudahan yang didapatkan masyarakat sebetulnya tingkat kerumitan dalam Inovasi Raskin Pola PKP ini pada tingkat rendah. Tingkat kerumitan dari Inovasi Raskin pola PKP ini dapat dilihat dari seberapa sulit masyarakat memahami inovasi ini dan seberapa sulit masyarakat beradaptasi. Dengan inovasi yang baru kemungkinan tingkat kerumitan menjadi lebih tinggi dari yang sebelumnya. Namun demikian, karena sebuah inovasi menawarkan cara yang lebih baik, sehingga hanya diperlukan proses adaptasi (Suwarno, 2008). 
Kualitas sebuah Inovasi menjadi hal yang sangat penting, Namun demikian kualitas sebuah inovasi juga harus dapat dibarengi dengan kesiapan masyarakat sebagai penerima manfaat sehingga sebuah inovasi dapat diterima. Inovasi hanya bisa diterima apabila telah teruji dan terbukti mempunyai keuntungan atau nilai lebih dibandingkan dengan inovasi yang lama (Miles B, Mathew, 1992). Begitu pula yang terjadi dalam Inovasi Raskin Pola PKP ini, Pemerintah Kab.TTU telah lebih dulu melakukan perencanaan pengelolaan Inovasi Raskin Pola PKP. Sebagai upaya agar Inovasi Raskin Pola PKP ini dapat menyesuaikan dengan kondisi dan kebutuhan masyarakat.

Luasnya lahan kering yang dimiliki oleh Kab. TTU ini menjadikannya daerah yang cukup potesial guna pengembangan pertanian ditambah lagi jumlah mayoritas masyarakat bergerak pada sektor pertanian. Namun disisi lain, lahan kering yang potensial ini juga berdampak pada kesulitan pangan khususnya beras pada musim kemarau panjang yaitu pada periode Juni hingga September. Keadaan ini membuat pemerintah mengupayakan untuk mengoptimalkan potensi sekaligus menyelesaikan persoalan dalam satu waktu menggunakan inovasi ini. Masyarakat yang tinggal di daerah lahan kering ini, pada saat tertentu akan kekurangan pangan terutama pangan beras. Keadaan yang paling terasa adalah pada saat musim kemarau panjang yaitu pada periode bulan Maret sampai Bulan November. Keadaan ini membuat pemerintah perlu mengintervensi dengan bantuan beras raskin.

Oleh karena itu, Inovasi Raskin Pola PKP ini harus dilakukan secara matang dari awal proses perencanaan, Perencanaan Pengelolaan Raskin Pola PKP juga bertujuan membuat estimasi volume kegiatan yang akan dilakukan di setiap Desa/Kelurahan. Pelaksanaan kegiatan dimulai sejak bulan Januari sampai dengan Bulan Desember (1 Tahun) dengan Waktu efektif yang dibutuhkan untuk mengimplementasikan satu tipe kegiatan yakni selama 2 (dua) bulan. Dalam setahun beras didistribusikan sebanyak 2 kali yaitu periode pertama untuk pekerjaan tahap I, II dan III (bulan Januari s/d Juni) dan periode kedua untuk pekerjaan tahap IV, V dan VI (bulan Juli s/d Desember). Pendistribusian Raskin Pola PKP periode pertama dilakukan pada bulan JuliAgustus dan pendistribusian periode kedua pada bulan Oktober-November.

Pertimbangan penetapan periode pembagian beras raskin ini, dapat menjadi gambaran bahwa Pemerintah Kab.TTU telah lebih dahulu melakukan penyesuaian dengan kondisi dan kebutuhan masyarakat. Penyesuaian kondisi dan kebutuhan masyarakat ini juga menjadi pintu awal bahwa sebuah inovasi dapat diujicobakan dalam masyarakat karena mampu diterima oleh masyarakat penerima manfaat dari Inovasi. Inovasi harus memiliki kemampuan untuk diujicobakan (Miles B, Mathew, 1992). Dengan perubahan waktu pembagian Raskin memungkinkan masyarakat untuk memiliki kesediaan pangan khususnya beras dalam pada masa panceklik.

Setelah melihat proses pelaksanaan kegiatan pembagian raskin, dapat diketahui bahwa perubahan pola pembagian beras raskin ini merupakan proses yang mudah dijalankan karena hanya mengganti periode waktu pembagian beras raskin. Selain proses yang mudah dijalankan Inovasi dalam pembagian beras raskin ini juga mudah untuk diamati oleh seluruh masyarakat pengguna manfaat dari inovasi ini. Proses pengamatan inovasi ini dapat dilakukan sejak tahap sosialisasi hingga tahap evaluasi. Sebuah inovasi harus dapat diamati dari segi bagaimana ia bekerja dan menghasilkan sesuatu yang lebih baik, dengan 
atribut seperti ini maka inovasi merupakan cara baru untuk menggantikan cara lama dalam mengerjakan atau memproduksi sesuatu. (Miles B, Mathew, 1992). Pengamatan Inovasi Raskin Pola PKP ini dapat dilihat dari awal proses sosialisasi program hingga evaluasi program Inovasi.

Tahap Sosialisasi menjadi tahapan yang sangat penting, dengan sosialisasi yang sudah dilakukan, memberikan kesempatan bagi masyarakat sebagai pengguna manfaat untuk mengamati serta memahami prosedur Inovasi Raskin Pola PKP. Tahap awal yang dilakukan pemerintah sebelum mengimplementasikan program Inovasi Raskin Pola PKP ini adalah dengan mensosialisasikan Program Inovasi Raskin Pola PKP ini kepada masyarakat melalui pola sosialisasi secara berjenjang yang diawali pada tingkay Kabupaten sampai ke tingakat Desa.

Selain itu, pengamatan juga dapat dilakukan melalui bagaimana inovasi Raskin Pola PKP ini dijalankan. Menurut Rongers, inovasi harus observability yaitu harus dapat diamati dari segi bagaimana ia bekerja (Miles B, Mathew, 1992). Dalam hal pengamatan pada proses Implementasi Inovasi Raskin Pola PKP pemerintah Kabupaten Timur Tengah Utara memaksimalkan peran dari penyuluh pertanian Lapangan, Penyuluh Pertanian Swakarsa Desa (PPSD), dan Mantri Tani sebagai pelaksana teknis di lapangan. Setidaknya pemerintah melibatkan 156 orang Penyuluh Pertanian Lapangan (PPL), 25 orang Penyuluh Pertanian Swakarsa Desa (PPSD) dan 24 orang Mantri Tani sebagai pelaksana teknis di lapangan bersama 2.100 orang Komite Desa pada 175 Desa/Kelurahan.

Sedangkan dalam hal evaluasi pengamatan dapat dilakukan dengan melihat bagaimana sebuah inovasi melakukan perbaikan dalam proses berjalannya Inovasi. Perbaikan yang dilakukan dapat melalui Pemberian masukan dan kritik juga diperuntukkan memperbaiki inovasi (Miles B, Mathew, 1992). Sistem yang diterapkan untuk memantau kemajuan dan mengevaluasi pelaksanaan Program Raskin Pola PKP yakni dengan melakukan monitoring dan evaluasi secara periodik atau sesuai kebutuhan yang dilaksanakan secara terpadu dengan metode kunjungan lapangan, diskusi lapangan dan rapat koordinasi.

Selain itu, pengamatan juga bisa dilihat dari korelasi antara tujuan dan capaian dari inovasi. Sebagai upaya menyukseskan tujuan akhir dari inovasi ini Pemerintah Kab.TTU memberikan ruang bagi penerima manfaat dalam hal ini petani dari Inovasi untuk melakukan perbaikan berupa penyampaian kritik, saran dan masukan yang tujuannya adalah pengembangan dan perbaikan dari Inovasi Raskin pola PKP ini sehingga dengan harapan inovasi ini dapat terusmenerus melakukan perbaikan. Dalam hal penyampaian saran dan kritik ini petani diberikan keleluasaan dalam menyampaikan kritik dan saran langsung kepada stakeholder terkait Inovasi Program Raskin Pola PKP ini. Pemerintah Kab.TTU meyakin bahwa semakin banyak wadah yang disediakan untuk menyampaikan kritik dan saran dari petani akan semakin baik proses evaluasi yang bisa dilakukan. Hal ini diketahui dari hasil wawancara penulis dengan perwakilan Dinas Pertanian bahwa kritik, saran dan keluhan bisa disampaikan kepada siapa saja, semakin banyak tempatnya semakin baik. Nanti didalam evaluasi yang dilakukan akan dibahas keluhan-keluhan tersebut.

Berdasarkan pernyataan diatas dapat diketahui bahwa upaya yang dilakukan pemerintah memberikan kesempatan bagi penerima manfaat Inovasi 
Raskin pola PKP untuk memahami prosedur dari Inovasi Raskin pola PKP. Dalam Impelmentasinya, dapat dilihat dari keberhasilan pelaksanaan dilapagan, semakin banyak masyarakat yang merasakan keuntungan dari Inovasi maka semak tinggi pula upaya yang harus dilakukan pemerintah untuk terus melakukan perbaikan melalui keluluasaan dalam penyempaian krtik, saran dan keluhan sebagai upaya pengembangan dan perbaikan dari Inovasi Raskin Pola PKP ini.

Dalam Inovasi Raskin pola PKP terdapat faktor pendukung yang dapat mendorong keberhasilan penyelenggaraan program Raskin pola PKP. Berdasarkan hasil penelitian yang dilakukan dalam hal ini faktor pendukung Inovasi Raskin pola PKP diantaranya adalah Komitmen Pemimpin. Komitmen ini dapat diliat dari kesungguhan dari semua tingkatan Pemerintah daerah Kab.TTU, dengan menempatkan pengembangan pertanian sebagai prioritas utama guna mengurangi angka kemiskinan, mencegah kerusakan lingkungan, mewujudkan ketahanan pangan dan peningkatan pendapatan tunai keluarga tani. Selain itu, komitmen Perangkat Desa dapat terihat dari beberapa desa telah membuat aturan dengan Peraturan Desa (Perdes) mengenai Kebun Menetap guna mendukung pelaksanaan Raskin Pola Padat Karya Pangan. Komitmen pemimpin adalah upaya keberlanjutan program Inovasi Raskin Pola PKP ini, Bupati Kab.TTU selaku inisiator dalam inovasi ini memiliki kepemimpinan dan wawasan yang memadai tentang pengelolaan pertanian.

Sedangkan faktor penghambat Inovasi Raskin Pola PKP ini adalah minimnya dukungan dari pihak legislatif untuk mengimpelemntasikan Inovasi Raskin pola PKP ini. Minimnya dukungan ini berdampak pada lamanya proses mediasi dengan legislative sehingga Inovasi Raskin pola PKP ini tidak dapat segera diimpelemntasikan. Minimnya dukungan berdampak pada terkendalanya impelementasi Inovasi Raskin pola PKP tahun awal implementasi dikarenakan adanya pemangkasan anggaran di legislatif. Namun demikian, Pemerintah tetap berkomiten untuk tetap melanjutkan Inovasi Raskin pola PKP ini.

Kendala yang dialami oleh Pemerintah Kab.TTU dalam mengimpelemtasikan Inovasi Raskin Pola PKP ini antara lain: Pertama, masih ada perangkat Desa/Lurah yang kurang berpartisipasi dalam pelaksanaan Raskin Pola Padat Karya Pangan (Raskin PKP) seperti tidak dilakukannya pemeriksaan kebun, beras dibagi tanpa petugas, dan tidak menandatangani form distribusi. Kedua, Masih ada oknum aparatur Desa/Kelurahan yang cenderung membagikan Raskin kepada semua Kepala Keluarga (termasuk PNS, Mantri Tani, PPL, Pensiunan). Ketiga, tipe pekerjaan sesuai Juknis belum dilaksanakan secara optimal. Solusinya adalah terus melakukan sosialisasi dan pendekatan terhadap masyarakat dengan memberdayakan petugas penyuluh lapangan (PPL). Keempat, tidak tersedianya benih tanaman penguat teras, Tanaman Umur Panjang dan tanaman sela di tingkat RTM sebagai bentuk dukungan dalam penerapan teknis budidaya yang lengkap. Kelima, masih ada RTM yang hasil kerjanya tidak mencapai target sesuai dengan norma kerja dalam JUKNIS PKP. Keenam, masih ada kecenderungan petani melakukan kebun berpindah-pindah dengan pola tebas bakar tanpa memaksimalkan potensi lahan yang dekat pemukiman. 


\section{PENUTUP}

Inovasi Raskin pola PKP ini lahir dari internal pemerintah Kabupaten TTU sebagai upaya pengembangan pada sector pertanian dengan tujuan untuk mengatasi masalah kemiskinan dan ketidakcukupan pangan dengan mengkonvenversikan raskin nasional dan masyarakat yang menjadi Rumah Tangga Sasaran penerima program raskin nasional untuk mengelola lahan sendiri dengan Pola Padat Karya Pangan. Inovasi ini memiliki banyak keuntungan bagi masyarakat, dengan mempertimbangkan kondisi dan pola pertanian sebelumnya dan mempertahankan nilai-nilai local yang ada dimasyarakat. Inovasi ini tidak termaksud dalam inovasi dalam tingkat kerumitan rendah karena sangat memungkinkan untuk diuji coba dan kemudahan untuk diamati. Keunggulan dalam inovasi ini adalah masyarakat memiliki lahan garapan yang menetap sekaligus mendapatkan beras raskin tanpa uang tebusan. Faktor pendukung yang mendorong keberhasilan penyelenggaraan program Raskin pola PKP ini adalah Komitmen Pemimpin. Sedangkan fator penghambat Inovasi Raskin Pola PKP ini adalah minimnya dukungan dari pihak legislatif.

Berdasarkan kesimpulan hasil penelitian tersebut, penulis menyarankan untuk merampingkan pelaksanaan teknis lapangan yang sebelumnya terdiri dari penyuluh pertanian Lapangan, Penyuluh Pertanian Swakarsa Desa (PPSD), dan Mantri Tani sebagai pelaksana teknis di lapangan. Hal ini sebagai upaya memaksimalkan tugas, pokok dan fungsinya. Pemisahan tugas, pokok dan fungsi ini menurut penulis dapat berdampak pada tumpang tindihnya kewenangan dari teknis lapangan. Selain itu, otimalisasi teknis lapangan ini juga sebagai upaya mengefisiensikan anggaran dalam Impelementasi Inovasi Raskin pola PKP.

\section{DAFTAR PUSTAKA}

A. Abdurachman, A. Dariah, dan A. M. (2008). Strategi dan Teknologi Pengelolaan Lahan Kering Mendukung Pengadaan Pangan Nasional. Balai Besar Penelitian Dan Pengembangan Sumberdaya Lahan Pertanian, 27(2), 43-49.

Anggraini, T. (2019). Inovasi Birokrasi Pelayanan Publik di Dinas Penanaman Modal dan Pelayanan Terpadu Satu Pintu (DPMPTSP) Di Kabupaten Musi Banyuasin Studi Kasus: (Siap Antar Jemput Izin Mudah Berbantuan (SAJI MUBA)). Politeia: Jurnal Ilmu Politik, 11(2), 44-57. https://doi.org/10.32734/politeia.v11i2.1122

Basuki, J. (2013). Budaya Pelayanan Publik. Hartono Media Pustaka.

Colville, I., \& Carter, M. (2012). Innovation and Change in Public Services. In L. Brown \& S. P. Osborne (Eds.), Handbook of Innovation in Public Services. Edward Elgar publishing.

Creswell, J. (2014). Research Design: Qualitative, Quantitative, and Mixed Methods Approaches. 4th Edition. The New Zealand Dental Journal, (Vol. 86).

Fatchiya, A., Amanah, S., \& Kusumastuti, Y. I. (2016). Penerapan Inovasi Teknologi Pertanian dan Hubungannya dengan Ketahanan Pangan Rumah $\begin{array}{llll}\text { Tangga Petani. Jurnal Penyuluhan, } & 190 .\end{array}$ https://doi.org/10.25015/penyuluhan.v12i2.12988

GenBest.id. (2018, September 20). Turunkan Kemiskinan Hingga 22 Persen, Bupati TTU Terima Penghargaan. Kompas.Com. 
Jordan, A., \& Huitema, D. (2014). Policy innovation in a changing climate: Sources, patterns and effects. Global Environmental Change, 29, 387-394. https://doi.org/10.1016/j.gloenvcha.2014.09.005

Miles B, Mathew, \& M. H. (1992). Analisis Data Kualitatif Buku Sumber Tentang Metode-metode Baru. UIP.

Muluk, M. . K. (2008). Knowledge Management: Kunci Sukses Inovasi Pemerintahan Daerah. Bayumedia.

Suwarno, Y. (2008). Inovasi di Sektor Publik. STIA-LAN Press.

Tsou, H. T., \& Hsu, H. Y. (2011). E-service Innovation within Open Innovation Network. Journal of Economics and Management Engineering, 5 (1), 31-36.

Victorino, L., Verma, R., Plaschka, G., \& Dev, C. (2005). Service innovation and customer choices in the hospitality industry. Managing Service Quality, 15(6), 555-576. https://doi.org/10.1108/09604520510634023 